\title{
COVID-19 Pandemisinin Çeşitli Etik Yönleri ve Veri Analitiği Üzerine Bir Değerlendirme
}

\author{
Gökhan ASLIM ${ }^{1} \oplus \varpi$, M. Agah TEKİNDAL ${ }^{2}$ (1) \\ ${ }^{1}$ Selçuk Üniversitesi Veteriner Fakültesi, Veteriner Hekimliği Tarihi ve Deontoloji Anabilim Dalı, Konya, Türkiye \\ ${ }^{2}$ İzmir Katip Çelebi Üniversitesi Tip Fakültesi, Biyoistatistik Anabilim Dalı, İzmir, Türkiye
}

Bu makaleye yapılacak atıf: Aslım G, Tekindal MA. COVID-19 Pandemisinin Çeşitli Etik Yönleri ve Veri Analitiği Üzerine Bir Değerlendirme. Turk J Diab Obes 2021;2: 226-232.

ÖZ

Koronavirüs hastalığı ortaya çıktığı ilk günden itibaren dünyanın dört bir yanında ülkeler, ekonomik, sosyal, yasal vb. pek çok alanda sorunlarla karşı karşıya kalmıştır. Tüm salgın hastalıklarda olduğu gibi, bu pandeminin de aşı çalışmaları, araştırma ve yayın etiği, çevre etiği, bilgi kirliliği gibi pek çok etik yönü dikkat edilmesi gereken konular arasında yerini almıştır. Ayrıca bu dönemde elde edilen verilerin doğru analizi, yorumlanması ve toplum sağlığı açısından kullanılması oldukça önemli bir konudur. Çalışmada da bu bağlamda COVID-19 pandemisinin içerdiği çeşitli etik konuların ve veri analitiğinin genel bir bakış açısıyla değerlendirilmesi amaçlandı. Hem mevcut pandemi hem de gelecekte yaşanabilecek olası pandemiler için etik değerlendirmelerin ve veri analizinin oldukça önemli ve muhakkak yararlanılması gereken konular olduğu söylenebilir.

Anahtar Sözcükler: COVID-19, Etik, Pandemi, Veri analitiği

\section{An Evaluation of the Various Ethical Aspects and Data Analytics of the COVID-19 Pandemic}

\begin{abstract}
Since the first day of coronavirus disease, countries worldwide have been involved in economic, social, legal, Etc. It has become a problem faced by many problems. As in all epidemic diseases, many ethical aspects of this pandemic such as vaccine studies, research and publication ethics, environmental ethics and information pollution have taken their place among the issues that need to be considered. In addition, the correct analysis, interpretation and use of the data obtained in this period for public health are critical. In this context, the study aimed to evaluate the various ethical issues and data analytics included in the COVID-19 pandemic from a general perspective. Therefore, it can be said that ethical evaluations and data analysis are critical and must be utilized for both the current pandemic and the possible future pandemics.
\end{abstract}

Keywords: COVID-19, Ethics, Pandemic, Data analytics

ORCID: Gökhan Aslım / 0000-0001-5976-8186, M. Agah Tekindal / 0000-0002-4060-7048 


\section{GİRIS}

Çin'in Wuhan kenti, Hubei bölgesinde takvimler 2019 yılı Aralık ayını gösterdiğinde, klinik açıdan viral pnömoniye benzeyen, solunum, sindirim ve çeşitli sistematik problemlere sebep olan yeni vakalar tespit edilmiş ve yapılan genetik analizde, yeni bir Koronavirüs türü olan "SARS-CoV-2" olduğu belirlenmiştir $(1,2)$. Tespit edilen bu hastalık oldukça kısa bir zaman diliminde tüm dünyaya yayılmış, 11 Mart 2020 tarihinden itibaren de Dünya Sağlık Örgütü (DSÖ) bu yeni Koronavirüs enfeksiyonunun küresel pandemiye yol açtığını ilan etmiştir (3).

Dünya şu anda, "1918 İspanyol Gribi” salgınından bu yana görülmemiş bir küresel halk sağlığı problemi ile karşı karşıyadır (4). Ortaya çıktığı ilk andan günümüze kadar gelen süreçte tüm dünyayı etkisi altına alarak 21. yüzyılın en önemli sağlık problemi hâline gelmiş olan COVID-19 pandemisinin, gelinen süreçte küresel anlamda yarattığı etkiler hâlen net olarak tanımlanamamıştır (5). Salgın, günlük yaşamlarımız üzerinde artan ve belirsiz bir etkiye işaret eden öngörülerle tıbbi bakım hizmetleri (6) bașta olmak üzere hayatın her yönünü etkilemeye devam etmektedir.

COVID-19 pandemisi, oldukça önemli bir küresel halk sağl1ğ1 problemi olması yanında, dünyada sosyolojik, ekonomik, politik, ekolojik açıdan farklı dönüşümleri de beraberinde getireceği düşünülen bir olgu olarak karşımıza çıkmıştır (7).

Oldukça hızlı bir şekilde yayılım gösteren enfeksiyon sebebiyle dünyanın dört bir yanında tıbbi kurumlar, tedavi umuduyla başvuran çok sayıda hasta ile karşı karşıya kalmış durumdadır (4). "Hastalik Kontrol ve Önleme Merkezleri”nin verdiği mesajlarından biri, COVID-19 salgınını yavaşlatmanın ve nihayetinde hayat kurtarmanın en etkili yolunun, yeni enfeksiyonların "eğrisini düzleștirmek" (8) ve onları daha geniş bir alana yaymak olduğudur. Böylelikle hastane yatakları, ventilatörler, doktorlar ve diğer sağlık personeli gibi "sınırl kaynakları" herhangi bir zaman noktasında daha uygun ve etkili şekilde kullanımı mümkün olabilecektir (9). COVID-19 salgını, sağlık hizmetleri sistemlerinin kapasitelerini artırmasıyla birlikte etik ikilemleri de beraberinde getirmiştir (10). Tüm salgın hastalıklarda olduğu gibi, COVID-19 pandemisinin de etik yönleri, dikkat edilmesi gereken konular arasında yerini almış ve salgın ile mücadelede önemli bir hareket noktası olmuştur (11). Bu konular, karar verici mercileri tüm toplumu mevcut sağlık sistemlerinin temellerini yeniden incelemeye zorlamaktadır (12).

Etik sözcüğü günümüzde, insanların tutum ve davranışlarının iyi (doğru) ya da kötü (yanlış) yönlerden değerlendirilmesi olarak tanımlanmaktadır. Etik alanında yapılan çalışmalar, mevcut değerlerin analizi, incelenmesi, değer kavramlarının anlamı, yorumu, iyi ve kötüyü araştırmak, yeni ilke-kuralların geliştirilmesi, ödev, yükümlülük ve toplumsal sorumluluk vb. kavramların değerlendirilmesi gibi çalışmalar olarak karşımıza çıkmaktadır (13). COVID-19 pandemi sürecine bakıldığı zaman da tıbbi etik, biyoetik, çevre etiği, araştırma ve yayın etiği gibi pek çok konuyu ilgilendiren durumlarla karşı karşıya kalındığı söylenebilir.

Bugüne kadar ülkemizde temel etik konular ve ilkeler $(14,15)$; sınırlı kaynakların adil dağıtımı $(11,14,15)$; triaj $(11$, 15-17); temel hizmetler ve tıbbi yarar (15), sağlık çalışanlarının durumu $(14,15,18,19)$; aşı çalışmaları, aşı güvenliği ve getirdiği etik sorunlar (20); tıp etiği (21); hemşireler için etik sorunlar $(17,18)$ gibi başlıklarda etik düzlem üzerinde çeşitli çalışmalar yapılmıştır. Çalışmada da COVID-19 pandemisinin içerdiği etik konuların bahsedilmeyen veya daha az bahsedilen hususları ile birlikte veri analitiğinin, genel bir bakış açısıyla değerlendirilmesi amaçlandı.

\section{ÇEŞITTLİ ETIK YÖNLERIYLLE COVID-19 PANDEMİSI}

Halk sağlığı açısından çok büyük bir tehdit olan COVID19 'un üstesinden gelmek için en etkili yolun "aşı" olduğu ve bu şekilde toplum bağışıklığının sağlanması gerektiği düşünülmektedir. COVID-19'a karşı aşı araştırma-geliştirme çalışmaları, dünya genelinde daha önce görülmemiş bir hız ve ölçekte devam etmektedir (20). Hastalığa karşı yapılan mücadelede oldukça hızlı hareket etme ve acilen bağışıkl1ğın sağlanması zorunluluğu "aşı güvenliği" ve "aşı etkinliği" açısından çeşitli problemlere neden olmaktadır. COVID-19 ile yapılan mücadelede yapılan çalışmaların etik olarak kabul edilebilirliği ve beklenen problemlere oranla halk sağlığı açısından sağlayacağı faydalar daha ağır basmaktadır (22). Pandeminin bir an önce sona ermesi için yapılan çalışmaların, bilim etiği uygulamalarını engellemeden yapılması ve araştırmacıların araştırma etiği ilkelerine sadık kalarak çalışmalarını yürütmesi oldukça büyük önem taşımaktadır $(22,23)$. Ayrıca yüksek bilimsel ve etik standartların sağlanması ile hem aşı çalışmalarına katılanların, hem de halkın aşılara olan güveninin korunması da sağlanacaktır (22).

Pandemi dönemlerinde etkili bir aşı bulunması yanında, bulunan aşıların hızla ve bol miktarda üretilmesi ile birlikte ücretsiz veya oldukça düşük ücretlerle halka dağıtılması da oldukça önemlidir. Bir yandan aşı çalışmaları tüm hızıyla devam ederken aşı uygulamalarının tüm dünyada başlaması ile birlikte aşı ile ilgili yoğun tartışmaların başladığ 1 da görülmektedir. Yapılan bu tartışmalar aşılarla ilgili endişeleri daha da artırmıştır. Bu endişelerin giderilmesi için aşıların etkinliği ve güvenliği konusunda şeffaf bir bilgilendirme yapılması ve elde edilen verilerin toplum ile paylaşılması büyük önem taşımaktadır (20). DSÖ’nün yaptığı tanımlamada "aşı kararsızlı̆̆ı" aşıya erişimin mümkün olduğu halde 
bazı aşı uygulamasını kabul etmekte gecikme ya da uygulanmasına izin vermeme; "aşı reddi" ise aşıları tümüyle reddetme durumudur. DSÖ, aşılarla ilgili oluşan tereddütlerin, bireysel ve kültürel gerekçelerden kaynaklanabileceği gibi, aşıya özgü herhangi bir sorundan kaynaklanabileceğini de belirtmekte, her ülkenin bu endişeleri ve tereddütleri gidermek, aşıların kabulünü ve aşılanma talebini artırmak için stratejiler geliştirmesini önermektedir (24).

COVID-19 ile ilgili ilk bilgiler 30 Aralık 2019 tarihinde Çin menşeili bir sosyal medya uygulamasında yayınlandı ve bir gün sonra 31 Aralık 2019 tarihinde de, Çin sağlık yetkilileri tarafindan resmi olarak açıklandı (25). Bu açıklamanın ardından biyomedikal alanda faaliyet gösteren bilimsel dergiler oldukça hızlı bir şekilde Koronavirüs ve pandemi ile ilgili veri ve bilgilerin yer aldığı çalışmaları yayınlamaya başladılar ve büyük bir rekabet içinde yayın süreci devam etmektedir. Yapılan bu hızlı bilgi paylaşımları gerekli ve takdire şayan olmakla birlikte, belirli riskleri de beraberinde getirmektedir. Örneğin düzeltildiğinde bile ortaya çıkardığ yanlışlar ve kamuoyunda algı oluşturma riski bulunmakta olup, bu yanlıșlıkların çeșitli nedenlerle daha da kötüleșme ihtimali bulunmaktadır (26). Dünyanın en prestijli tıp dergilerinden ikisinde yayınlanan iki farklı ve yüksek profilli çalışma, metodolojik ve veri bütünlügü ile ilgili yaşanan sorunlardan dolayı geri çekilmek zorunda kalmıştır (27).

Mevcut risklerin bilimsel yayının bütünlüğü, doğruluğu ve değerini artıracak yayın etiği ilkeleri ile desteklenmesi ve giderilmesi de oldukça önemlidir (26). "American Journal of Biomedical Science \& Research" dergisinde yayınlanan "Cyllage City COVID-19 Outbreak Linked to Zubat Consumption" (28) adlı pokemonlardan esinlenerek hazırlanan ve yalnızca dört günde kabul edilip basılan "uydurma makale", yayın etiği açısından olayın gelebileceği noktaları oldukça net bir şekilde gözler önüne sermektedir.

Salgının başlamasıyla birlikte vakaların izole edilmesi ve virüsün sirkülasyonunu kısitlamak için insanlar evlerine kapatılmışlardır. Kapanma dönemleri, hava kirliliğinin azalmasına, kentsel temasın yoğun olduğu sularda kirliliğin azalmasını ve bu sulardaki canlılığın tekrar artmaya başlamasını sağlayarak çevre etiği açısından oldukça dikkat çekici bir durum olarak karşımıza çıkmıştır (21). Yurtsever (29), yapılan çalışma sonuçlarına göre, salgının başlamasıyla beraber uygulanan kısmi ve tam kapanma önlemleri sayesinde bazı gazların "hava kirletici konsantrasyonlari"nın önemli ölçüde azaldığını ve hava kalitesinde iyileşme olduğunu bildirmiştir. Bununla birlikte yapılan çalışmalarda salgın azaldığında veya bittiğinde hava kalitesinde yaşanan iyileşmenin uzun vadeli olamayacağ 1 ve eskiye dönüleceği de belirtilmektedir $(30,31)$.
Çevre sorunlarının temel sebebinin insanlar olduğu düşünüldüğünde insanların alışkanlıklarını, yaşam tarzlarını, inanışlarını, hissetme ve görme biçimlerini (32), kısacası dünyaya bakış açılarını değiştirmeleri kaçınılmaz bir hâl almıştır. Bu bağlamda salgından sonra yaşanacak süreçte de insanların bakış açılarını değiştirerek çevremerkezci bir anlayışla çevreye ve doğaya özenli ve saygılı bir davranış sergilemelerinin önemli bir husus olduğu söylenebilir.

COVID-19 pandemisi, durmak bilmeyen bir hızla ilerlerken psiko-sosyal belirsizliğini korumaya da devam etmektedir (9). Salgının neden olduğu yıkım, biyoetik açıdan pek çok zorlu ikilemi ortaya çıkarmıştır (10). Bakıldığında mevcut COVID-19 salgını ile ilgili zorlu etik sorunlardan bazıları, kişisel koruyucu ekipman azlığı ve virüse yakalanma riski, birçok sağlık hizmeti sağlayıcısını gerçek etik sorumluluğun ne olduğunu düşünmeye zorlamasıdır (4). Bu doğrultuda sağlık profesyonellerinin yaşadığ 1 etik kaygıların altında yatan nedenlerin ve kaynaklarının araştırılması adına biyoetik ve sosyal bilimler alanında çalışmalar yapmak önem taşımaktadır. Bu çalışmalar, mevcut pandemi ve gelecekte yaşanması kaçınılmaz olan yeni salgın hastalıklarla mücadele politikaları ve araştırmalarının ayrılmaz bir parçası hâline gelecektir (33).

Bütün bunlarla birlikte bireylere düşen ve her bireyin yerine getirmesi gereken etik sorumluluklar olduğunu da unutmamak gerekir. Salgının seyri açısından sürekli vurgulanmakta olan "maske, mesafe ve temizlik" mottosunun ülkemizde yok sayıldığı çeşitli olaylar meydana gelmiş ve alınan tüm önlemlere rağmen 1srarlı bir şekilde yasaklara uyulmadığ durumlarla karşı karşıya kalınmıştır (34-36). Bunların önüne geçmek için idari yaptırımlar ve düzenlemeler önemli olmakla birlikte, bireylerin de diğer bireylerin iyiliği ve toplum yararı bilincini taşıması, hissetmesi ve o doğrultuda davranışlar sergilemesi gerektiği söylenebilir.

Pandemi süresince yaşanan önemli sorunlardan birisi de medya organlarında çok fazla "bilgi kirliliği" yaşanmasıdır. Pandemi ile birlikte sosyal medyada çok fazla yalan haber ve bilgi üretilip, insanlara gerçekmiş gibi sunulmuştur. Hatta bu konu DSÖ'nün de dikkatini çekmiş ve salgınla ilgili olarak sosyal medyada ortaya çıkan bu bilgi kirliliğini "infodemi" şeklinde tanımlamış ve bunun da halk sağl1ğını tehdit eden önemli bir durum olduğu ifade edilmiştir (37). Ülkemizde de pandemi sürecinin başında, konusunda uzman olmayan kişiler ekranlarda yer alıp, salgın ile ilgili görüşlerini beyan ederken, salgının ilerlemesi ve bilgilerin artmasıly birlikte, konusunda uzman kişilerin ekranlarda daha fazla yer almaya başladığı görülmüştür. Salgınla ilgili önemli hususlardan biri de hastalıkla ilgili istatistiki verilerdir. Bu verilerin devlet yetkilileri tarafından doğru ve şeffaf 
bir şekilde kamuoyuna aktarılması gerekmektedir (38). Bu durumların sağlanmasının, toplumun doğru bilgiye ulaşımı ve bireylerin "bilgi edinme hakkı" adına oldukça önemli olduğu söylenebilir.

\section{COVID-19 SÜRECINNIN VERİ ANALITTIĞİ KAPSAMINDA DEĞERLENDİRMESI}

İnsanlığın varoluşundan 2000'li yıllara kadar üretilen veri miktarı, günümüzde birkaç dakika içinde üretilebilmektedir. $\mathrm{Bu}$ nedenle büyük veriden ve akıllı analizlerden yararlanmak ve bunu halk sağlığı için iyi bir şekilde kullanmak gerekmektedir (39). Günümüz dijital dünyasında da COVID-19 salgınını yönetmek için büyük veriler kritik öneme sahiptir. Tahmin ve gözetim için dijital olarak mevcut verilerin ve algoritmaların kullanımının (örneğin hastalığın yayıldığı bölgelere seyahat eden kişilerin belirlenmesi veya enfekte kişilerin temaslarını izleyerek izole etmenin) COVID-19 ile mücadelede büyük önem taşıdığ 1 ifade edilmektedir. Bununla birlikte, bu verileri ve algoritmaları sorumlu bir şekilde, veri koruma düzenlemelerine uygun olarak, "mahremiyet" ve "gizliliğe saygı" çerçevesinde kullanmak da aynı derecede önemlidir. Aksi takdirde bunu yapmamak, halkın güvenini zayıflatacak, bu da insanların halk sağlığı konusunda verilen tavsiyelere uyma olasıllğını azaltacak ve daha kötü sağlık sonuçlarına sahip olma olasılığını artıracaktır (40).

COVID-19 salgınında, geçmiş verilerin nasıl kullanılacağı ve gelecekteki davranışların nasıl tahmin edileceği konusunda büyük belirsizlikler söz konusu (41) olmakla birlikte, COVID-19'un neden olduğu bu belirsizlik ve benzeri görülmemiş zorluklara etkili bir şekilde yanıt vermek için veriye dayalı kararlara yönelim olmuştur (42). Pandemi sürecinde elde edilen veriler sürekli değişkenlik göstermekle birlikte, sahadan elde edilen verilerin hızlı ve etik açıdan uygun paylaşımı, salgının kontrol altına alınmasında, mevcut ve yeni tedavilerin değerlendirilmesinde ve sınırlı kaynakların etkili kullanılmasinda rehberlik edecektir (43).

Pandemi sürecinde toplumun, tanı ve teşhis testlerinin gerekliliği ve bunların sonuçlarını, test doğruluğu ölçütlerini, tarama stratejilerini, hastalık oluşum oranları gibi temel istatistiksel kavramları anlaması biyoistatistik gibi bir disiplinin, COVID-19 pandemisi deneyimine sunması ve sağlaması gereken hususlar olarak göze çarpmaktadır. Günlük hasta ve vaka sayılarına dayanan istatistiksel modellerin, COVID-19'un yarattığı krizin biyoistatistik alanında ne gibi bir etkisi olacağının sorgulanmasını sağlamak, doğru bilgiye ulaşmak adına faydalı olacaktır (44).

Veri analitiği açısından bakıldığında COVID-19 sürecini modellemek, gelecekte bu hastalıkla ilgili anlayışımızı geliştirmeye önemli katkılar sağlayabilir. Bu modeller ve yaklaşımlar hastalıkla ilgili araştırmaları şekillendirmek için değerli katkılar sağlayacaktır. Virüsün nasıl yayıldığını ve bulaşma olasılıklarını tahmin etmek, şüpheli bir kişinin koşullarını sürekli gözlemleyecek bir sistem geliştirerek COVID-19 olup olmadığını otomatik olarak tahmin etmek; farklı aşıların ve tedavilerin COVID-19 hastaları üzerindeki etkisini tahmin etmek gibi konularda veri analizi oldukça faydalı olabilir (45).

\section{AŞI ve ÍLAÇ ARAŞTIRMALARINDA BIYYOISTATISTTIĞİN ÖNEMİ}

HIV/AIDS'in ortaya çıtığı ilk dönemlerde metodolojik șekilde yapılan çalışmalardan olan "Zidovudin (ZDV)" - "Azidotimidin (AZT)" olarak da bilinen-, hastalığı önlemek ve tedavi etmek için kullanılan ve "Gıda ve İlaç Dairesi (FDA)" tarafından onaylanan ilk ilaç olmuştur. Onayın temeli olan klinik araştırma, "New England Journal of Medicine" adlı derginin Temmuz 1987 sayısında yayınlanmasına (46) rağmen FDA tarafından onaylanma hikâyesinin tartışmaya açı olduğu değerlendirilmiştir. Tartışma yaratmasının nedenlerinden birisi, yapılacak ilaç denemeleri için çok merkezli bir biyoistatistik değerlendirme yapılmaması ve uluslararası kriterlerin oluşturulamaması olmuştur. Bu durum katılımcılar üzerinde yapılan ișlemlerde farklılıklar olușturmuș ve ilacın etkinliğinin ve güvenirliğinin sorgulanmasına neden olmuştur (44). COVID-19 pandemisinde yapılacak olan aşı ve ilaç geliştirme çalışmalarında çok merkezli biyoistatistik değerlendirmelerin yapılması ve uluslararası kriterlerin sağlanarak katılımcılar üzerinde denemelerin yapılması gerektiği ileri sürülebilir.

İlaç geliştirme programlarının büyük bir kısmının geç aşama doğrulayıcı klinik araştırmalarda bir tedavinin etkinliğini göstermek için tasarlandığ 1 ve güvenlik sonuçlarının genellikle birincil odak olmadığ ve önceden belirtilmedikçe güvenlik sonlanım noktalarının kapsamlı bir şekilde değerlendirilmediği bilinmektedir. Yapılan ölçümlerde uç noktalarda beklenmedik sonuçlar ortaya çıkabilmektedir ve bu durumun etkinlik sonuçlarında olduğu gibi önceden tanımlanmasının oldukça zor olduğu belirtilmektedir. Bununla birlikte, daha az dikkat çekmekte olan ilaç güvenliğiyle ilgili durumlar da uzun süredir tartışılmaya devam etmektedir. $\mathrm{Bu}$ riski değerlendirmek için tasarlanmış yüksek profilli çalışmalar için önemli biyoistatistik uzmanlığ 1 gerektiren yeni ilaçların güvenlik değerlendirmeleri, oldukça önemli adımlar olarak karşımıza çıkmaktadır (44). Bu bağlamda COVID-19 pandemi sürecinde de bu konulardan doğru şekilde yararlanılmasının önemli olduğu söylenebilir.

Yeni ilaçların ve biyolojik maddelerin küresel gelișimi ve özellikle de biyoistatistik uygulamaları ve disiplini üzerinde istatistiksel kılavuzlar önemli etkilere sahiptir. Çünkü ilaç 
ve aşı geliştirme alanında çalışmakta olan tüm biyoistatistik uzmanları belirtilen hususları tam anlamıyla uygulamak ve ilkelere bağlı kalmak zorundadır. Bugüne kadar istatistiksel uygulamaları etkileyen üç önemli kılavuz geliştirilmiştir. Geliştirilen bu kılavuzların, klinik ilaç geliştirilmesi, klinik araştırmalardaki eksik veri sorununu ele alması, tedavi etkinliklerinin artırılması gibi küresel anlamda istatistiksel uygulamaların iyileştirmesine katkı sağlaması amaçlanmıştır (47-50). Bu doğrultuda istatistiksel olarak ülkeler arasindaki oranlarda farklılıkların ortaya koyulması ve etkin tedavi yöntemlerinin klinik denemelerinin planlanması ve ölçülmesi ile hem içsel hem de dişsal faktörlerin potansiyel etkilerinin belirlenmesi gerektiği söylenebilir. COVID-19 pandemisi sürecindeki mevcut durum, veri kalitesine, sağlam biyoistatistiksel planlama ve analiz yöntemlerine, kılavuzlara/ortak standart uygulamalara olan ihtiyacı net bir şekilde göstermektedir. Bu bağlamda da yapılacak klinik araştırmalara katkı sağlanması amacıyla biyoistatistik uzmanları aracılığıyla mevcut istatistik kılavuzlardan yararlanılmasının ve/veya yeni bir kılavuz geliştirmenin salgının olası çözümlerinde rol oynayıp oynamayacağını görmek adına önemli olduğu ileri sürülebilir.

Pandemi süresince COVID-19 için iki ana hastalık modellemesi yapılmış olup bunlar, "öngörüsel modeller" ve "regresyon modelleri" olmuştur. Ayrıca birden çok zaman serisini, Markov süreçlerini, öngörüsel ayarlama stratejilerini ve hassasiyet analizlerini içerecek şekilde de bilim insanları tarafından hızla geliştirilmeye ve araştırılmaya devam ettiği görülmektedir. Bu yaklaşımlardan bazıları, ortak veri modeli yaklaşımlarının da hızlanması gerektiğinden, ağ tabanlı veri tabanlarına dayanan ulusal ve yerel düzeylerde gelişmiş öngörüsel yöntemlere de oldukça ciddi katkıda bulunmaktadır (44). Gelinen noktada hastalıkla ilgili yapılacak tahminlerin türleri, kapsamı ve bu tahminlerdeki önyargıların ve belirsizliklerin nitelendirilmesi oldukça hassas ve kritik bir konudur. Bu sebeplerle biyoistatistik uzmanlarının güncel yöntemleri uygulamak, yeni yöntemler ve ölçütler geliştirmek için işbirliğine içerisinde pandemi sürecine katılımı oldukça önemlidir.

\section{SONUÇ}

Sonuç olarak, içinde yaşadığımız COVID-19 pandemisi süreci her alanda pek çok konuyu gündeme getirmiş olmakla birlikte, bu sürecin beraberinde daha neleri getireceği, neleri götüreceği net olarak bilinmemektedir. Bu sebepten dolayı pandeminin sonlandırılması adına tüm dünyanın birlikte hareket etmesi, karar vermesi, bu zorlu ve bilinmez konuların üstesinden nasıl gelinebileceğine dair politikalar üretmesi gerekmektedir. İşte bu noktada çözülmesi gereken pek çok soruna karşı etik rehberliğinde, bilimden ve bilimsel yöntemlerden şaşmadan, veri analizi ve modelleme gibi biyoistatistiki yöntemlerden yararlanarak çözüm önerileri geliştirmelidir. Bu öneriler doğrultusunda da pandemi ile mücadele etmek, hem mevcut pandemi, hem de gelecekte yaşanabilecek olası pandemiler açısından oldukça büyük önem taşımaktadır.

Teşekkür

Yok.

Yazarların Makaleye Katkı Beyanı

Fikir ve tasarım: Gökhan Aslım, Mustafa Agâh Tekindal, Literatür taraması: Gökhan Aslım, Mustafa Agâh Tekindal, Denetim: Gökhan Aslım, Mustafa Agâh Tekindal, Veri toplanması ve işlenmesi: Gökhan Aslım, Mustafa Agâh Tekindal, Analizler ve yorumlar: Gökhan Aslım, Mustafa Agâh Tekindal, Makale yazımı: Gökhan Aslım, Eleştirel inceleme: Gökhan Aslım, Mustafa Agâh Tekindal

Çıkar Çatışması

Yazarlar, hiçbir çıkar çatışması bulunmadığını beyan eder.

Finansal Destek

Araştırmada hiçbir bir kurum veya kuruluştan finansal destek alınmamıştır.

\section{Etik Kurul Onayı}

Yayın için etik kurul onayı gerekmemektedir.

\section{Hakemlik Süreci}

Kör hakemlik süreci sonrasında yayınlanmaya uygun bulunmuş ve kabul edilmiştir.

\section{KAYNAKLAR}

1. Huang C, Wang Y, Li X, Ren L, Zhao J, Hu Y, Zhang L, Fan G, Xu J, Gu X, Cheng Z, Yu T, Xia J, Wei Y, Wu W, Xie X, Yin W, Li H, Liu M, Xiao Y, Gao H, Guo L, Xie J, Wang G, Jiang R, Gao Z, Jin Q, Wang J, Cao B. Clinical features of patients infected with 2019 novel coronavirus in Wuhan, China. Lancet. 2020;395:497-506.

2. Li Q, Guan X, Wu P, Wang X, Zhou L, Tong Y, Ren R, Leung KSM, Lau EHY, Wong JY, Xing X, Xiang N, Wu Y, Li C, Chen Q, Li D, Liu T, Zhao J, Liu M, Tu W, Chen C, Jin L, Yang R, Wang Q, Zhou S, Wang R, Liu H, Luo Y, Liu Y, Shao G, Li H, Tao Z, Yang Y, Deng Z, Liu B, Ma Z, Zhang Y, Shi G, Lam TTY, Wu JT, Gao GF, Cowling BJ, Yang B, Leung GM, Feng Z. Early transmission dynamics in Wuhan, China, of novel coronavirus-infected pneumonia. N Engl J Med. 2020;382(13): 1199-1207.

3. World Health Organization (WHO) (2020). WHO Timeline - COVID-19. (Erişim: https://www.who.int/news-room/ detail/27-04-2020-who-timeline---covid-19 Erişim tarihi:15 Şubat 2021.)

4. Angelos P. Surgeons, ethics, and COVID-19: Early lessons learned. J Am Coll Surg. 2020; 230(6):1119-1120. 
5. Aslım HP, Dik I, Gülbahçe R, Bulut O. Modern çağın sorunu: Covid-19. Eurasian J Vet Sci. 2020; Covid-19 Special Issue: 1116.

6. Zhou F, Yu T, Du R, Fan G, Liu Y, Liu Z, Xiang J, Wang Y, Song B, Gu X, Guan L, Wei Y, Li H, Wu X, Xu J, Tu S, Zhang Y, Chen $\mathrm{H}$, Cao B. Clinical course and risk factors for mortality of adult inpatients with COVID-19 in Wuhan, China: A retrospective cohort study. Lancet. 2020; 395: 1054-1062.

7. Nicola M, Alsafi Z, Sohrabi C, Kerwan A, Al-Jabir A, Iosifidis C, Agha M, Agha R. The socio-economic implications of the coronavirus and COVID-19 pandemic: A review. Int J Surg. 2020;78:185-193.

8. Centers of Disease Control and Prevention (CDCP) (2020). Interim infection prevention and control recommendations for patients with suspected or confirmed Coronavirus Disease 2019 in healthcare settings. (Erişim: https://www. cdc.gov/coronavirus/2019-ncov/infection-control/controlrecommendations.html. Erişim tarihi: 17 Şubat 2020.)

9. Shuman AG, Pentz RD. Cancer research ethics and COVID-19. Oncologist. 2020; 25(6): 458-459.

10. Sabatello M, Blankmeyer T, McDonald KE, Appelbaum PS. Disability, ethics, and health care in the COVID-19 Pandemic. AJPH. 2020;110(10):1523-1527.

11. Köken AH (2020). Etik yönleriyle Coronavirüs (Covid 19) pandemisi. Ankara Barosu Sağlık Hukukunda COVID-19 Bülteni. (Erişim: http://www.ankarabarosu.org.tr/upload/ EkSayfa/diger/SHK/20200514eyc.pdf Erişim tarihi: 20 Şubat 2021).

12. Rosenbaum L. Facing Covid-19 in Italy-ethics, logistics, and therapeutics on the Epidemic's front line. N Engl J Med. 2020;382(20):1873-1875.

13. Aydın E. Tıp etiğine giriş. Pagem A Yayıncılık, Ankara, 2001.

14. Yalçınkaya E. Covid-19 ve getirdiği etik sorunlar. Türkiye Biyoetik Dergisi. 2019;6(3):122-127.

15. Örnek Büken N. COVID 19 pandemisi ve etik konular. Sağlık ve Toplum Dergisi. 2020; Özel Sayı: 15-26.

16. Üstün Ç, Özçiftçi S. COVID-19 pandemisinin sosyal yaşam ve etik düzlem üzerine etkileri: Bir değerlendirme çalışması. Anadolu Kliniği Tıp Bilimleri Dergisi. 2020; 25 (Özel Sayı 1): 142-153.

17. Arın Namal F, Alkan E. COVID-19 hastaları ve etik: Hekimlere triaj önerileri. COVID-19 Pandemisi ve Etik. 1. Baskı. Ankara: Türkiye Klinikleri; 2021; 1-9.

18. Palandöken E. COVID-19 pandemisi ve hemşireler için etik sorunlar. İzmir Kâtip Çelebi Üniversitesi Sağlık Bilimleri Fakültesi Dergisi. 2020; 5(2): 139-142.

19. Leblebicioğlu H, Nair Aktaş F. Covid-19 salgınıyla mücadele: Yoğun bakım hemşireliği meslek ve kişisel etik perspektifi. Yoğun Bakım Hemşireliği Dergisi. 2020; 24(EK-1): 73-80.

20. Topçu İ, Nasuhbeyoğlu N. Gen düzenleme teknolojileri bağlamında covıd-19 aşı çalışmaları ve etik sorunlar. Anadolu Kliniği Tıp Bilimleri Dergisi. 2020; 25 (Özel Sayı 1): 274-284.
21. Çobanoğlu N. Bireysel, profesyonel, toplumsal, bilimsel ve siyasal etiği yeniden sorgulatan COVID-19 pandemisi. Anadolu Kliniği Tıp Bilimleri Dergisi. 2020; 25 (Özel Sayı 1): 36-42.

22. Jamrozik E, Selgelid M. COVID-19 human challenge studies: Ethical issues. Lancet Infect Dis. 2020; 20: 198-203.

23. UNESCO (2020). COVID-19 hakkında açıklama: Global bakış açısıyla etik konular üzerine görüş. (Erişim: https://unesdoc. unesco.org/ark:/48223/pf0000373115_tur Erişim tarihi: 20 Şubat 2021).

24. World Health Organization (WHO) (2020). Improving vaccination demand and addressing hesitancy. (Erişim: www.who.int/immunization/programmes_systems/vaccine_ hesitancy/en Erişim tarihi: 20 Mayıs 2021).

25. Lei R, Qiu R. (2020). Chinese bioethicists: silencing doctor impeded early control of coronavirus. (Erişim: https:// www. thehastingscenter.org/coronavirusdoctor- whistleblower. Erişim tarihi: 16 Şubat 2021).

26. Smith MJ, Upshur REG, Emanuel EJ. Publication ethics during public health emergencies such as the COVID-19 Pandemic. AJPH. 2020; 110(7): 947-948.

27. Robinson K. A false promise of COVID-19 'big' health data? Health data integrity and the ethics and realities of Australia's health information management practice. Health Inf Manag. 202; 50(1-2): 9-12.

28. Elm U, Joy N, House G, Schlomi M. Cyllage City COVID-19 outbreak linked to zubat consumption. American Journal of Biomedical Science \& Research. 2020; 8(2): 140-142.

29. Yurtsever M. COVID-19 Pandemisinin çevre üzerindeki erken dönem etkileri. Uludağ Üniversitesi Mühendislik Fakültesi Dergisi. 2020;25(3): 1611-1636.

30. McCloskey B, Heymann DL. SARS to novel coro-navirus-old lessons and new lessons. Epidemiol Infect. 2020;148 (e22): 1-4.

31. Saadat S, Rawtani D, Hussain CM. Environmental perspective of COVID-19. Science of the Total Environment. 2020;728 (2020): 1-7.

32. Ünder H. Çevre felsefesi etik ve metafizik görüşler. Ankara, Doruk Yayımcilık, 1996.

33. Meagher K, Cummins NW, Bharucha AE, Badley AD, Chlan LL, Wrigt S. COVID-19 ethics and research. Mayo Clin Proc. 2020; 95(6): 1119-1123.

34. Habertürk (2021). Uludağ'da korona parti! (Erişim: https:// www.haberturk.com/pes-dedirten-olay-son-dakika-uludagda-korona-parti-2949559. Erişim tarihi: 20 Şubat 2021).

35. Sputniknews (2021). Yasaklara rağmen nişan eğlencesi: Maskeleri mendil yapıp halay çektiler. (Erişim: https:// tr.sputniknews.com/turkiye/202102141043809457-yasaklararagmen-nisan-eglencesi-maskeleri-mendil-yapip-halaycektiler/ Erişim tarihi: 20 Şubat 2021).

36. Hürriyet (2021). Yasağa rağmen açık kahvenin sahibi ile kağıt oynayan 12 kişiye para cezası. Erişim: https://www.hurriyet. com.tr/gundem/yasaga-ragmen-acik-kahvenin-sahibi-ilekagit-oynayan-12-kisiye-para-cezasi-41715344. Erişim tarihi: 20 Şubat 2021). 
37. Aydın AF. Post-truth dönemde sosyal medyada dezenformasyon: Covid-19 (Yeni Koronavirüs) pandemi süreci. Asya Studies-Academic Social Studies. 2020; 4(12): 7690.

38. Türk Tabipleri Birliği (TTB) (2020). Türk Tabipleri Birliği olarak 6 aydır söylediklerimizi Sayın Bakan doğruladı: Turkuaz tablo kara tabloya dönüştü. (Erişim: https://www.ttb. org.tr/haber_goster.php?Guid=bdcc7294-0405-11eb-85e4b78881f13431. Erişim tarihi: 20 Şubat 2021).

39. Ienca M, Vayena E. On the responsible use of digital data to tackle the COVID-19 pandemic. Nature Medicine. 2020; 26: 458-464.

40. Ward PR. Improving access to, use of, and outcomes from public healthprograms: The importance of building and maintaining trust with patients/clients. Front Public Health. 2017; 5(22.):1-7.

41. World Health Organization (WHO). Guidance For Managing Ethical Issues In Infectious Disease Outbreaks. World Health Organisation. (Erişim: https://apps.who.int/iris/ handle/10665/250580. Erişim tarihi: 31 Mart 2021).

42. Brown S. How COVID-19 is disrupting data analytics strategies. (Erişim: https://mitsloan.mit.edu/ideas-made-tomatter/how-covid-19-disrupting-data-analytics-strategies. Erişim tarihi: 31 Mart 2021).

43. Sheng J, Amankwah-Amoah J, Khan Z, Wang X. COVID-19 Pandemic in the new era of big data analytics: Methodological innovations and future research directions. British Journal of Management. 2020;0:1-20.

44. O'Neill RT. Reacting to crises: The COVID-19 impact on biostatistics/epidemiology. Contemp Clin Trials. 2021;102:106214.
45. Mondal MRH, Bharati S, Podder P, Podder P. Data analytics for novel coronavirus disease. Inform Med Unlocked. 2020; 100374: 1-13.

46. Fischl MA, Richman DD, Grieco MH, Gottlieb MS, Volberding PA, Laskin OL, Leedom JM, Groopman JE, Mildvan D, Schooley RT. The efficacy of Azidothymidine (AZT) in the treatment of patients with AIDS and AIDS-related complex. N Engl J Med. 1987;317(4):185-191.

47. Food and Drug Administration (FDA) (2016). Real-world evidence. (Erişim: https://www.fda.gov/science-research/ science-and-research-special-topics/real-world-evidence. Erişim tarihi: 15 Şubat 2021).

48. Food and Drug Administration (FDA) (2018a). Meta-Analyses of Randomized Controlled Clinical Trials to Evaluate the Safety of Human Drugs or Biological Products Guidance for Industry, Draft. https://www. fda.gov/media/117976/download. Erişim tarihi: 15 Şubat 2021).

49. Food and Drug Administration (FDA) (2018b). Avandia (rosiglitazone) labels now contain updated information about cardiovascular risks and use in certain patients. (Erişim: https://www.fda.gov/drugs/drug-safety-and-availability/fdadrug-safety-communication-avandia-rosiglitazone-labelsnow-contain-updated-information-about. Erişim tarihi: 15 Şubat 2021).

50. Food and Drug Administration (FDA) (2018c). FDA requires removal of some prescribing and dispensing restrictions for rosiglitazone-containing diabetes medicines. (Erişim: https://www.fda.gov/drugs/drug-safety-and-availability/fdadrug-safety-communication-fda-requires-removal-someprescribing-and-dispensing-restrictions. Erişim tarihi: 15 Şubat 2021). 